\title{
Breadfruit in Nutrition and Health in the French Caribbean Islands
}

\author{
J. Nacitas ${ }^{1}$, K. Rochefort', G. Aurore ${ }^{2}$, B. Ganou-Parfait ${ }^{3}$, S. Adenet' and L. Fahrasmane ${ }^{3}$ \\ 1 Pôle Agro-alimentaire Régional de Martinique (PARM), 97232 Lamentin, France \\ ${ }^{2}$ Université des Antilles-Guyane, UMR1270 QUALITROP, 97110 Pointe-à-Pitre, France \\ ${ }^{3}$ INRA Antilles-Guyane, UMR 1270 QUALITROP, 97170 Petit-Bourg, France
}

Keywords: breadfruit, Artocarpus altilis, Caribbean

\begin{abstract}
The seedless breadfruit, Artocarpus altilis, synonymous Artocarpus communis, was a forgotten vegetable prior 1939. It was the cornerstone of the diet of many West Indians during World War II years. It is a member of the Moracea. The fruit is produced abundantly. It is estimated that yields in terms of kilocalories of energy per ha could compare with corn. However, breadfruit is classified as NUS (neglected and under-utilised crops species) on the IPGRI list. The future of breadfruit as a food or raw material in food processing seems promising. To promote breadfruit nutritional benefits, more analysis and objective information are needed on molecular, physiochemical properties, and digestibility of its starch.
\end{abstract}

\section{INTRODUCTION}

Breadfruit (Artocarpus altilis (Parkinson) Fosberg var. non seminifera, Moraceae), has significant potential to contribute to food needs in the French Islands of the Caribbean region. The fruit can be cooked and eaten at all stages of maturity, is high in carbohydrates, and is a good source of minerals, carotenoïds (Beyer, 2007), and vitamins (Engelberger et al., 2007). These constituents have been found to have important health benefits, protecting against cancer, heart disease, diabetes and protection against vitamin A deficiency. In addition to producing abundant, nutritious, tasty fruits, this multipurpose tree provides animal feed, construction materials, and medicine (Beyer, $2007)$. The mature fruit has high moisture content $(62.7-89.2 \%$ fresh weight). The nutrient composition in $100 \mathrm{~g}$ fresh weight indicates a low energy level (91-109 Kcal), low proteins (1.3-2.4 g), lipids (0.1-0.86 g) and fibers (1.08-2.1 g) but appreciable quantities of starch (15-18 g). The fruit is also source of other bioactive compounds as flavonoids (artocarpin, artocarpesine), and lectines (jacaline).

\section{Origin of Breadfruit}

The breadfruit is native to the area extending from New Guinea through the IndoMalayan Archipelago and western Micronesia. Breadfruit in the Caribbean and elsewhere in the tropics originated from those. The French brought breadfruit to their Caribbean colonies: Martinique, Guadeloupe and Cayenne received a variety from Tonga named "kélé" (Zerega et al., 2006). When breadfruit trees begun to produce fruits in the Caribbean islands, the slaves refused to eat this foreign food and it was instead of it used to feed animals. Only fifty years after abolition did Caribbean people begin to eat it themselves. Today, breadfruit is listed among NUS (Neglected and Under-utilized crop Species) (Knudsen et al., 2008). The research and the marketing of manufactured products are still at their stammering.

\section{MATERIALS AND METHODS}

\section{Plant Material}

Three main types of breadfruit found in the French Caribbean Islands are the "yellow heart", the "white heart" and the "frizzy" cultivars. The "White Heart' cultivar of breadfruit, common cultivar, was harvested from several trees in domestic orchards in Martinique (French West Indies). 120 samples were analyzed during stage mature-green breadfruit. At this stage, fruits are ready to harvest and eat as a starchy staple in 
15-19 weeks. The pulp of the fruits was sliced, frozen with a fast freezing room at $-25^{\circ} \mathrm{C}$ for subsequent analysis.

\section{Analytical Methods}

The nutritional analysis and $\mathrm{pH}$ of all samples was determined following AOAC

methods. Protein content was calculated by multiplying nitrogen content by a factor of 5.4. Total soluble solids ( ${ }^{\circ}$ Brix) were measured at room temperature on centrifuged aqueous solution (4000 rpm for $15 \mathrm{~min}$ ) using an Abbe refractometer with a measuring range of $0-32^{\circ}$ Brix. Starch was measured by the UV method (Boehringer Mannheim, 1977) with correction for endogenous glucose. Starch from mature-green breadfruits were extracted in water and in $\mathrm{NaOH}$, purified and characterized. Thermal characteristics were monitored by differential scanning calorimetry (DSC). Phenolic compounds were measured in pulp aqueous acetone extracts. Flavonoids present in the extracts were identified and quantified using an HPLC DAD (Agilent 1100 series).

\section{RESULTS AND DISCUSSION}

The nutrient composition in $100 \mathrm{~g}$ fresh weight of mature fruit indicates a low energy level (109-151 Kcal), low proteins (1.1-2.4 g), lipids (0.1-0.86 g) but appreciable quantities of starch (15-18 g). Starch was found to contain $21.0 \%$ amylose, $78.1 \%$ amylopectin and $0.9 \%$ other minors compounds. Its thermal characteristics were: temperatures of onset $\left(T 0=57.8^{\circ} \mathrm{C}\right)$, peak $\left(T \mathrm{p}=65.6^{\circ} \mathrm{C}\right)$, and conclusion $\left(T \mathrm{c}=72.6^{\circ} \mathrm{C}\right)$ of gelatinization and the endothermic enthalpy $(\mathrm{H})$, gelatinisation $=21.5 \mathrm{~J} / \mathrm{g})$. The fruit is also source of bioactive compounds of which are flavonoids.

\section{CONCLUSION}

Breadfruit trees interesting role in traditional agro-forestry systems and their fruit high productivity are assets to be taken into account by economic forces (Ragone, 1997). This underutilized starchy fruit will never become more than a locally important crop unless reliable methods of extending its shelf-life and commercially processing it are developed. The future for breadfruit as a food or raw material for nutrition and health seems promising. To promote nutritional benefits of breadfruit, more analysis and objective information are needed on molecular and physiochemical properties, on digestibility of starch from French West Indies cultivars.

\section{Literature Cited}

Beyer, R. 2007. Breadfruit as a candidate for processing. Acta Hort. 757:209-214.

Englberger, L., Alfred, J., Lorens, A. and luta, T. 2007. Screening of selected breadfruit cultivars for carotenoids and related health benefits in Micronesia. Acta Hort. 757:193-200.

Knudsen, I., Soborg, I., Eriksen, F. Pilegaard, K. Pedersen, J. 2008. Risk management and risk assessement of novel plant foods: concepts and principles. Food and Chemical Toxicology 46:1681-1705.

Ragone, D. 1997. Promoting the Conservation and Use of Underutilized and Neglected Crops Series, vol. 10: Breadfruit, Artocarpus altilis (Parkinson) Fosberg. Rome: Ed.: International Plant Genetic Resources Institute.

Zerega, N.J.C., Ragone, D. and Motley, T.J. 2006. Breadfruit origins, diversity, and human - facilitated distribution. p.213-238. In: T.J. Motley, N. Zerega and H. Cross (eds.), Darwin's Harvest: New Approaches to Origins, Evolution, and Conservation of Crop Plants. Columbia University Press, New York. 